AT-TAJDID: Jurnal Pendidikan Dan Pemikiran Islam

(p-ISSN: 2548-5784 le-ISSN: 2549-2101)

Vol. (04 )(01), (Januari-Juni) (2020), (Halaman)(75-84)

Doi: http://dx.doi.org/10.24127/att.v4i01.1225

\title{
INKLUSIFISTAS PEMIKIRAN DAN PENDIDIKAN ISLAM TERHADAP PERSPEKTIF KARL R. POPPER
}

\author{
Oleh \\ Bahrun Ulum \\ PONPES Bani Rosul Gubug Sekeping Purwokerto Barat \\ Bahrunulum543@gmail.com
}

\begin{abstract}
ABSTRAK
Inklusivistas Pemikiran Pendidikan Islam terhadap perspektif Karl R. Popper merupakan sebuah konsep tawaran untuk pendidikan pesantren tentang falsifikasi Karl R. Popper. Popper adalah seorang filsuf kontemporer yang melihat kelemahan dalam prinsip verifikasi berupa pembenaran (justification) terhadaap teori yang telah ada. Ia mengajukan prinsif falsifikasi; Pertama, Popper menolak anggapan umum bahwa suatu teori dirumuskan dan dapat dibuktikan kebenarannya melalui prinsip verifikasi, sebagaimana yang dianut oleh kaum positivistik. Teori-teori ilmiah selalu bersifat hipotetis (dugaan sementara), tak ada kebenaran terakhir. Setiap teori selalu terbuka untuk digantikan oleh teori yang lebih tepat. Kedua, cara kerja metode induksi yang secara sistematis dimulai dari pengamatan (observasi) secara teliti gejala yang sedang diselidiki. Ketiga, Popper menawarkan pemecahan baru dengan mengajukan prinsip falsifiabilitas, yaitu bahwa sebuah pernyataan dapat dibuktikan kesalahannya. Penulis berharap dengan adanya pemaparan tulisan ini dapat menambah semangat epistemologi Popper, falsafikasi dapat dijadikan langkah untuk menyadarkan dan membangkitkan kembali gairah dan semangat ilmiah umat Islam. Islam niscaya inklusif terhadap pemikiran lain dan harus dengan percaya diri bisa menanggapi serangan paham lain dan keberanian untuk melahirkan hipotesa (konjektur) harus dibangkitkan.
\end{abstract}

Kata Kunci: falsifikasi, Pendidikan Islam, Inklusifitas Islam

\begin{abstract}
The Inclusiveness of Islamic Thinking and Education on the perspective of Karl R. Popper is an offer concept for Islamic Education about the falsification of Karl R. Popper. Popper is a contemporary philosopher who sees weaknesses in the verification principle in the form of justification against existing theories. He proposed the principle of falsification; First, Popper rejects the general notion that theory is formulated and can be verified through the principle of verification, as held by positivists. Scientific theories are always hypothetical (provisional estimates), there is no final truth. Every theory is always open to being replaced
\end{abstract}


by more appropriate theory. Second, the way the induction method works systematically begins with careful observation of the symptoms being investigated. Third, Popper offers a new solution by proposing the principle of falsifiability, namely that a statement can be proven wrong.

The author hopes that with the presentation of this article can increase the spirit of Popper's epistemology, falsification can be used as a step to awaken and revive the scientific passion and enthusiasm of Muslims. Islam is necessarily inclusive of other thoughts and must confidently respond to the attacks of other understandings and the courage to give birth to a hypothesis (conjecture) must be raised.

Keywords: Falsification, Islamic Inclusivity, Islamic Education

\section{A. PENDAHULUAN}

Dalam perkembangan ilmu pengetahuan barat terjadi berbagai macam interest yang saling bertentangan antara satu aliran filsafat satu dengan yang lainnya. Sebagaimana contohnya Plato, Filsuf yunani yang menggunakan metode deduksi menyatakan bahwa satusatunya pengetahuan yang sejati hanyalah berkaitan dengan konsepkonsep. Plato menggunakan pendekatanpendekatan yang bersifat rasionaldeduktif. Baginya pengetahuan hanya dihasilkan dengan menggunakan rasio atau akal, perolehan yang dihasilkan dari indra tidak laik disebut pengetahuan.

Kemudian dari pada itu konsep rasional-deduktif dari Plato dibantah oleh Aristoteles. Menurutnya konsep atau idea itu terbentuk dari observasi yang dilakukan oleh indra. Dari konsepsi ini lah disebut dengan konsep empirismeInduktif yaitu metode yang berangkat dari pengamatan indrawi terhadap beberapa kasus yang bersifat partikuler atau khusus kemudian dipakai untuk menciptakan hukum umum dan mutlak perlu atau disebut proses generalisasi.

Ajaran Aristoteles sendiri mengilhami aliran empirisme yang dikenalkan Davit Hume yang kemudian dipersempit lagi oleh aliran positivisme walaupun Hume sendiri menolak "proses generalisasi". Hume mengatakan bahwa kita tidak dapat mengetahui sesuatu apapun sebagai keseluruhan. Terutama kita tidak dapat mengetahui hakikat dari sesuatu apa pun. Kita juga tidak dapat mengetahui sesuatu tentang Allah bahkan tentang hakikat orang lain. Mengapa? Karena seluruh pengetahuan kita adalah terbatas pada pengalaman-pengalaman inderawi, jadi pada kesan-kesan yang kita terima melalui indera (Franz Magnis Suseno: 1992) .

Sementara Popper sendiri dalam hal ini setuju dengan Hume, bahwa peralihan dari yang partikuler ke universal itu secara logis tidak sah. Secara khusus, Popper mengkritik pandangan neo-positivisme (Vienna Circle), yang menerapkan pemberlakuan hukum umum. Kelompok ini membuat garis pemisah antara pernyataan yang bermakna (meaningfull) dan yang tidak bermakna (meaningless). Disebut bermakna jika dapat dibuktikan secara empiris-positive dengan metode induktifverifikatif. Dengan metode ini, aliran empirisme-positive menolak kebenaran metafisika dan agama. Popper berbeda pandangan dengan mereka yang mengatakan bahwa suatu teori umum dapat dirumuskan dan dibuktikan kebenarannya melalui prinsif verifikasi. Pemikiran Karl Popper menarik untuk dibahas karena tawaran teori falsifikasinya yang kontroversial dan 
melawan mainstream kala itu. Dalam kaitannya dengan pemikiran pendidikan Pesantren, penulis berupaya menelusuri asumsi dasar Popper mengenai bagaimana epistemologi falsafikasionisme Popper bagi Ilmu pengetahuan, bagaimana ilmu pengetahuan dapat dikatakan berkembang dan bagaimana implementasi-implementasinya terhadap pendidikan dan pemikiran Islam.

\section{B. BIOGRAFI TOKOH}

Karl Raimund Popper lahir pada tahun 1902 di Wina, Austria. Kedua orang tuannya adalah keturunan Yahudi, tetapi setelah menikah mereka dibaptis di gereja Protestan (K. Bertens: 1983). Ayahnya adalah seorang pengacara, sarjana hukum, dan senang membaca buku. Sedangkan ibunya piawai dalam bermain musik, sehingga tak heran jika Karl R. Popper juga amat perhatian pada masalah musik.

Ketika umurnya sekitar 17 tahun Popper pernah menganut aliran politik komunisme. Namun, ia kemudian meninggalkan aliran politik itu sambil mengkritik para penganutnya yang menerima dogmatisme secara tidak kritis. Pendidikannya ia tempuh di Universitas Wina. Di Sana, ia mempelajari banyak bidang, seperti kesusasteraan, sejarah, filsafat, ilmu kedokteran, dan psikologi. Tahun 1928, ia mendapat gelar doktor filsafat. Tahun 1935 dan 1936, berturutturut, ia mengajar di beberapa tempat di Inggris. Tahun 1937, karena totaliterisme Hitler yang menjalar ke Austria, Popper meninggalkan Austria dan mencari pekerjaan keluar negeri, yaitu sebuah universitas di Christchurch, Selandia Baru.

Usai perang dunia II, popper diangkat sebagai dosen di London School of Economics. Ia kemudian memperoleh kewarganegaraan Inggris. Setelah namanya terkenal lewat karya-karyanya, ia sering diundang untuk memberikan kuliah umum diberbagai negara di eropa, Amerika, Autralia, dan Jepang. Ia sangat menikmati pekerjaannya sebagi filsuf.

Popper meninggal pada 17 September 1994 dalam usia 92 tahun. Sepeninggalnya, perpustakaan pribadinya yang berisi sekitar enam ribu eksemplar buku dan seluruh warisan tertulisnya dibeli oleh negara Autria dan ditempatkan dalam perpustakaan Klagenfurt, Australia. Tujuan pembelian dan penempatan tersebut adalah agar apa yang telah dihasilkan oleh filsuf asal Austria itu dapat dipelajari oleh semua peminat.

\section{ISI PEMIKIRAN FILSAFAH}

Popper merupakan orang yang mendekontruksikan seluruh positivisme maupun neo-positivisme melalui metode falsifikasi.

Menurut Popper, verifikasi itu tidak ada, yang absah hanyalah Falsifikasi, artinya pencarian fakta yang memastikan bahwa sebuah hipotesis tidak dapat dipertahankan (tidak mungkin membuktikan bahwa semua burung gagak berwarna hitam; tetapi kalau ada seekor burung gagak saja yang berwarna putih, hipotesis bahwa semua burung gagak itu hitam, jatuh; selama hipotesis belum jatuh, hipotesis itu boleh dipertahankan). Pendekatan ini menyangkal bahwa pernyataanpernyataan tentang realitas alami lebih rasional dari pada pernyataan-pernyataan lain (Franz Magnis Suseno: 2005).

It never occurred to me, either in those day or leter, to propose testability or refutability or falsifiability as a criterion of meaning (as opposed to 
'meaning nonsense'); and when I first heard, in 1927 criterion of meaning, I at once objected to this procedure on two entirely different grounds: first, because taking meaningfulness as a criterion of damarcation meant branding metaphysics as meaningless gibberish: a dogma which I felt unable to accept; and secondly, because verifiability was proposed as a criterion of demarcation: a solution which was entirely inadequate, and indeed the opposite of what was needed. Por I could show that it was both too narrow and too wide: it (unitentionally) declared scientific theories to be meaningless, and it thereby placed them (again unitentionally) on the same level as metaphysich (cp. Section 4 of my L. Sc. D. And Appendix *ii) (Karl R. Popper: 2002).

Ini tidak pernah terjadi kepada saya, baik pada mereka hari atau leter, mengusulkan testability atau refutability atau falsifiability sebagai kriteria makna (sebagai lawan 'yang berarti omong kosong'); dan ketika saya pertama kali mendengar, pada tahun 1927 kriteria makna, saya langsung keberatan prosedur ini pada dua alasan yang sama sekali berbeda: pertama, karena mengambil kebermaknaan sebagai kriteria damarcation berarti merek metafisika omong kosong sebagai berarti: dogma yang saya merasa tidak dapat menerima ; dan kedua, karena pemastian diusulkan sebagai kriteria demarkasi: solusi yang sepenuhnya tidak memadai, dan memang kebalikan dari apa yang dibutuhkan. Por saya bisa menunjukkan bahwa itu adalah baik terlalu sempit dan terlalu lebar: itu (sengaja) menyatakan teori-teori ilmiah untuk menjadi tidak berarti, dan dengan demikian menempatkan mereka (lagi tidak sengaja) pada tingkat yang sama seperti metaphysich (cp Bagian 4 saya L. Sc. . D. Dan Lampiran * ii)
Secara khusus Popper mengkritik pandangan neo-positivisme (vienna Circle), yang menerapkan pemberlakuan hukum umum, dan menganggapnya sebagai teori ilmiah. Seperti telah diketahui, mereka memperkenalkannya dengan sebutan ungkapan bermakna (meaningfull), untuk membedakannya dari ungkapan yang tidak bermakna (meaningless) berdasarkan kriteria dapat atau tidaknya dibenarkan secara empiris. Popper berbeda anggapan dengan mereka yang mengatakan bahwa suatu teori umum dapat dirumuskan dan dibuktikan kebenaranya melalui prinsif verifikasi. Bagi popper, suatu teori tidak bersifat ilmiah hanya karena bisa dibuktikan (kebenarannya), melainkan karena dapat diuji (testable), dalam artian dapat diuji dengan percobaan-percobaan sistematis untuk menyangkalnya. Apabila suatu hipotesa atau suatu teori dapat bertahan melawan segala penyangkalannya, maka kebenaran hipotesa atau teori tersebut semakin diperkokoh (corraboration). Makin besar kemungkinan yang menyangkal suatu teori dan jika teori itu terus bisa bertahan, maka semakin kokoh pula kebenarannya.

Menurut Popper, teori-teori ilmiah selalu dan hanya bersifat hipotesis (dugaan sementara), tak ada kebenaran terakhir. Setiap teori selalu terbuka untuk digantikan oleh teori yang lebih tepat. Untuk itu Popper lebih suka menggunakan istilah hipotesa, atas dasar kesementaraannya. Upayanya ini, ia sebut dengan the thesis of refutability suatu ungkapan atau hipotesa bersifat ilmiah jika secara prinsipil terdapat kemungkinan untuk menyangkalnya (refutability). Dengan demikian perlu adanya kemungkinan untuk menjalankan kritik. Ilmuan yang sejati tidak akan takut pada kritik, sebaliknya ia sangat mengharapkan kritik, sebab hanya 
melalui jalan kritik ilmu pengetahuan terus mengalami kemajuan (Mohammad Muslih:2004).

Pandangan Popper ini, sekaligus menunjukan bahwa proses pengembangan ilmu bukanlah dengan jalan akumulasi, dalam artian pengumpulan bukti-bukti positif atau bukti-bukti yang mendukung suatu teori, sebagaimana pandangan neo-positivisme. Bagi Popper, proses pengembangan ilmu adalah dengan jalan eliminasi terhadap kemungkinan kekeliruan dan kesalahan (error elimination). Lebih jauh, untuk membuktikan pandangannya itu, ia menggunakan bukti-bukti sejarah ilmu dalam hal ini koreksi (error elimination) dari Einstein terhadap fisika Newton, dimana setelah diskusi beberapa waktu, para ahli kemudian sepakat dalam menerima fisika Einstein sebagai lebih memuaskan dari pada fisika Newton untuk menerangkan gejala-gejala fisis dalam dunia kita. Bagi popper, kemajuan ilmiah itu dicapai lewat dugaan dan penyanggahan dan semangat kritik diri (self-critical) adalah esensi ilmu. (Mohammad Muslih: 2004)

This is a view of science which takesits critical aproach to be its most important characteristic. Thus a scientist should look upon a theory from the point of view of whether it can be critically discussed: whether it exposes itself to criticism of all kinds; and - if it doeswhether it is able to stand up to it.Newton's theory, for example, predicted deviations from kepler's laws (due to the interactions of the planets) which had not been observed at the time. It exposed itself thereby to attempted empirical refutations whose failure meant the success of the theory. Einsten's theory was tested in a similar way. And indeed, all real tests are attempted refutations. Only if a theory succesfully withstands the pressure of these attempted refutations can we claim that it is confirmed or corroborated by experience (Karl R. Popper: 1992). Ini adalah pandangan ilmu yang mengambil pendekatan kritis untuk menjadi karakteristik yang paling penting. Dengan demikian seorang ilmuwan harus memandang teori dari sudut pandang apakah itu dapat kritis dibahas: apakah itu menghadapkan dirinya untuk kritik dari semua jenis; dan - jika tidak-apakah ia mampu berdiri untuk itu. Teori Newton, misalnya, diperkirakan penyimpangan dari hukum Kepler (karena interaksi dari planet-planet) yang belum diamati pada saat itu. Hal terkena itu sendiri dengan demikian bantahanbantahan empiris berusaha yang gagal berarti keberhasilan teori. Teori Einstein diuji dengan cara yang sama. Dan memang, semua tes nyata berusaha refutations. Hanya jika teori berhasil tahan tekanan ini refutations berusaha bisa kita mengklaim bahwa itu dikonfirmasi atau dikuatkan oleh pengalaman.

Popper melihat beberapa kelemahan prinsip verifikasi Lingkaran Wina, antara lain: pertama, prinsif verifikasi tidak pernah mungkin digunakan untuk menyatakan kebenaran hukum-hukum umum. Hukum-hukum umum dalam ilmu pengetahuan tidak pernah dapat diverifikasi. Karena seperti halnya metafisika, harus diakui seluruh ilmu pengetahuan alam (yang sebagian besar terdiri dari hukum-hukum umum) adalah tidak bermakna. Kedua, berdasarkan prinsif verifikasi, metafisika disebut tidak bermakna, tetapi dalam sejarah dapat disaksikan bahwa acap kali ilmu pengetahuan lahir dari pandanganpandangan metafisis atau bahkan mistis tentang dunia. Suatu ungkapan metafisis bukan saja dapat bermakna tetapi bisa 
juga benar, meskipun baru menjadi ilmiah kalau sudah diuji dan dites. Ketiga, untuk menyelidiki bermakna atau tidaknya suatu ungkapan atau teori, lebih dulu harus bisa dimengerti. Sehingga bagaimana bisa dimengerti jika tidak bermakna, lantas apa yang disebut teori. Kiranya atas dasar ini Popper selanjutnya mengajukan prinsip falsifikasi sebagai ciri utama ilmiah (Mohammad Muslih: 2004) .

Falsifikasi berbeda dengan falsifiabilitas, falsifiabilitas hanya untuk menunjukan ciri-ciri empiris suatu sistem pernyataan. Suatu teori disebut telah difalsifikasi hanya jika telah menerima pernyataan-pernyataan dasar yang menyangkalnya.

Kita mengatakan bahwa suatu teori difalsifikasi hanya jika kita telah menerima pernyataan-pernyataan dasar yang menyangkalnya (bdk. Seksi 11, aturan 2). Syarat ini penting, namun tidak mencukupi; karena kita telah melihat bahwa kejadian-kejadian tunggal yang tidak dapat diulangi tidak berarti bagi ilmu. Dengan demikian, segelintir pernyataan-pernyataan dasar yang sesat, yang menyangkal sebuah teori hampir tidak mendorong kita menolaknya sebagai yang sudah difalsifikasi. Kita akan menganggapnya sudah difalsifikasi hanya jika kita telah menemukan suatu akibat yang dapat direproduksi yang menyangkal teori itu. Dengan kata lain, kita hanya menerima falsifikasi itu jika suatu hipotesis empiris berlevel rendah yang melukiskan akibat tersebut diajukan dan dikorroborasikan (Karl R. Popper: 2008).

Berbeda dengan David Hume, Filsuf Positivisme, yang dalam satu hal mempunyai kesamaan dalam menolak "proses generalisasi", Popper merupakan orang yang tidak mengesampingkan kebenaran wahyu dan metafisik. Ia mempunyai konsep dunia tiga.

Popper membedakan realitas menjadi apa yang disebut; dunia satu yakni kenyataan fisis dunia; Dunia dua, yakni segala kejadian dan kenyataan psikis dalam diri manusia; dan dunia tiga, yakni segala hipotesa, hukum dan teori ciptaan manusia dan hasil kerjasama antara Dunia Satu dengan dunia dua serta seluruh bidang kebudayaan, seni, metafisik, agama dan lain-lain (Muhammad Muslih: 2004). Menurut Franz Magnis, rasionalitas ilmu teologi, misalnya harus dikembangkan baik dalam diskursus antara para teolog dari agama yang bersangkutan sendiri maupun dalam diskursus dengan kalangan luar: dengan teolog agamaagama lain, dengan para filosof, dengan pernyataan-pernyatan ilmu-ilmu lain yang misalnya menyerang. Disini metode falsifikasi Karl Popper cukup penting. Disatu pihak, teologi tidak perlu merasa minder terhadap ilmu-ilmu lain. Ia mempunyai rasionalitas sendiri. Dilain pihak, sikap percaya diri hanyalah wajar apabila semua tantangan dan serangan ditanggapi. Artinya, teologi tidak boleh tinggal di menara gading. Ia berkembang justru dengan menanggapi segala macam tantangan, baik yang tidak bermutu, misalnya karena berdasarkan prasangka (lalu teologi harus memperlihatkan dimana letak prasangka itu), maupun, apalagi, yang serius (Franz Magnis Suseno: 2005).

Popper seorang filsuf kontemporer yang melihat kelemahan dalam prinsip verifikasi berupa pembenaran (justification) terhadaap teori yang telah ada. Ia mengajukan prinsif falsifikasi yang dapat diurai sebagai sebagai berikut.

Pertama, Popper menolak anggapan umum bahwa suatu teori 
dirumuskan dan dapat dibuktikan kebenarannya melalui prinsip verifikasi, sebagaimana yang dianut oleh kaum positivistik. Teori-teori ilmiah selalu bersifat hipotetis (dugaan sementara), tak ada kebenaran terakhir. Setiap teori selalu terbuka untuk digantikan oleh teori yang lebih tepat.

Kedua, cara kerja metode induksi yang secara sistematis dimulai dari pengamatan (observasi) secara teliti gejala yang sedang diselidiki. Pengamatan yang berulang-ulang itu akan memperlihatkan adanya ciri-ciri umum yang dirumuskan menjadi hipotesa. Selanjutnya hipotesa itu dikukuhkan dengaan cara menemukan bukti-bukti empiris yang dapat mendukungnya. Hipotesa yang berhasil dibenarkan (justifikasi) akan berbuah menjadi hukum. Popper menolak kerja diatas, terutama pada asas verifiabilitas, bahwa sebuah pernyataan itu dapat dibenarkan berdasarkan bukti-bukti pengamatan empiris.

Ketiga, Popper menawarkan pemecahan baru dengan mengajukan prinsip falsifiabilitas, yaitu bahwa sebuah pernyataan dapat dibuktikankesalahannya. Maksudnya, sebuah hipotesa, hukum ataukah teori kebenarannya hanya bersifat sementara, sejauh belum ditemukan kesalahankesalahan yang ada didalamnya. Jika ada pernyataan "semuaangsa itu berbulu putih", melalui prinsif falsifiabilitas itu cukup ditemukan seekor angsa yang berbulu selain putih (entah, hitam, kuning, dan lain-lain), maka runtuhlah pernyataan semula. Bagi popper, ilmu pengetahuan dapat berkembang maju manakala suatu hipotesa telah dibuktikan salah, sehingga dapat digantikan dengan hipotesa baru. Namun ada kemungkinan lain, yaitu hanya salah satu unsur hipotesa yang dibuktikan salah untuk digantikan dengan unsur baru yang lain sehinga hipotesa telah disempurnakan. Menurut Popper, apabila suatu hipotesa dapat bertahan melawan segala usaha penyangkalan, maka hipotesa tersebut semakin diperkokoh (corroboration) (Rizal muntansyir \& Misnal Munir: 2006).

Untuk itu, falsifikasi menjadi metode atau alat untuk membedakan genuine science (ilmu murni) dari apa yang disebut Popper sebagai psedoscience (ilmu tiruan). Karena itulah Popper mengatakn, "science is revolution in permanence and criticism is the heart of the scientific enterpris" jadi, kriteria keilmiahan sebuah teori adalah teori itu harus bisa disalahkan (falsifiability), bisa disangkal (refutability) dan bisa diuji (testability). Pemikiran Popper ini mengantarkannya dikenal sebagai epistemolog rasionalisme-kritis dan empiris modern (Mohammad Muslih:2004).

\section{Analisis Epistemologi}

Setelah menyimak pemaparan singkat mengenai filsafat Popper di atas, penulis berpendapat teori Popper akan membuat ilmuan atau pemikir senantiasa ragu dengan kebenaran pengetahuan yang didapatinya dan secara psikologis berdampak pada ketegangan antar para ilmuan mengingat akan selalu dikritik dan diuji untuk diketemukan kesalahan teorinya. Teori Popper tidak pernah seratus persen yakin akan kebenarannya itu. Kondisi seperti ini akan menjebak seorang ilmuwan ke dalam dunia relativisme. Pasalnya semua observasi yang dilakukan oleh seorang ilmuwan tidak dimaksudkan untuk menguatkan bukti kebenaran hipotesis. Artinya seorang ilmuwan harus meninggalkan usahanya untuk mencari kepastian mutlak dalam pengetahuan manusia. 
Karena pengetahuan yang diperoleh selamanya akan bersifat sementara (tentative), selalu harus diuji, dan ilmu pengetahuan tak akan pernah final pada satu titik tertentu.

Namun demikian, setidaknya dalam satu sisi, pemikiran Popper akan memberikan nuansa yang berbeda dengan para pendahulunya yang serempak mencampakkan metafisika. Nampaknya Popper memahami betul bahwa pencampakan metafisika telah menjadikan ilmu pengetahuan bersifat ambivalen atau perasaan bertentangan dengan kenyataan. Maksudnya kemajuan sains saat itu dan sekarang ini harus dibayar mahal dengan hilangnya nilainilai spiritualitas pada alam ini.

It is important to realize that a proof of intrinsic meaninglessness would have to be valid with respect to every consistent language and not merely with respect to every language that suffices for empirical science. Few metaphysicians assert that metaphisical stantments belong to the field of the empirical sciences; and nobody would give up metaphysics because he is told that its statement cannot be formulated within these sciences (or within some language suitable for these sciences). After all, Wittgenstein's and Carnap's original thesis was that methapysics is absolutely meaningless-that it is sheer gibberish and nothing else; that it is, perhaps, of the character of sighs or groans or tears (or surealist poetry), but not of articulate speech. In order to show this, it would be quite insfficient to produce a proof to the needs of science. But even this insufficient proof has been produced by anybody, in spite of the many attempts to construct metaphysicsfree languages for sciences. Some of these attempts will be discussed in the nexs two sections (Karl R. Popper: 1992).
Adalah penting untuk menyadari bahwa bukti berartinya intrinsik harus berlaku sehubungan dengan setiap bahasa konsisten dan tidak hanya berkenaan dengan setiap bahasa yang mencukupi untuk ilmu pengetahuan empiris. Beberapa metafisika menegaskan bahwa pernyataan metapisik milik bidang ilmu empiris; dan tak seorang pun akan menyerah metafisik karena ia diberitahu bahwa pernyataannya tidak dapat dirumuskan dalam ilmu-ilmu ini (atau dalam beberapa bahasa yang cocok untuk ilmu-ilmu ini). Setelah semua, tesis asli Wittgenstein dan Carnap adalah bahwa metafisika benar-benar berarti-bahwa itu adalah omong kosong belaka dan tidak ada yang lain; bahwa itu adalah, mungkin, dari karakter mendesah atau erangan atau air mata (atau puisi surealist), tetapi tidak berbicara mengartikulasikan. Untuk menunjukkan hal ini, itu akan cukup memadai untuk menghasilkan bukti untuk kebutuhan ilmu pengetahuan. Tetapi bahkan bukti tidak cukup ini telah diproduksi oleh siapa saja, terlepas dari banyak upaya untuk membangun bahasa metafisika bebas untuk ilmu. Beberapa upaya ini akan dibahas dalam dua bagian berikutnya

\section{Implikasi terhadap pemikiran}

\section{Islam}

Ilmu pengetahuan dan peradaban dalam dunia Islam telah berkembang sangat pesat, dalam Islam terbentuk beragam bidang keilmuan sebut saja ilmu kalam, ilmu fikih, filsafat keilmuan bahasa (nahwu, sharaf, balaghah, uslubiyah). Dalam masing-masing khazanah keilmuan tersebut telah banyak melahirkan penemuan-penemuan ilmiah dari para ulama Islam. 
Dalam Ilmu sejarah (tarikh) memunculkan Atthabari, Ibnu Hazm, Ibnu Khaldun dan Ibnu Maskawaih. Dalam fikih misalnya memunculkan banyak tokoh, yang paling utama Imamimam madzhab. Dalam filsafat kita akan dibuat kagum oleh para filsuf misalnya al-Kindi dan Ibnu Rusydi yang berkebangsaan arab. Kemudian Ibnu Sinna, Suhrawardi, dan Mulla Sandra dari Persi yang mempunyai pandangan filsafat Islami. Beberapa tokoh dalam dunia Islam menulis sejumlah karya filsafat, misalnya Muhammad Ibn Zakariya' al-Razi (w. 320/932). (Seyyed Hossein Nasr: 2009). Walaupun dikatakan filsafat al-razi tidak Islami.

Dalam bidang logika, musisi, ahli metafisika dan pemikir politik kita kenal dengan yang namanya Abu Nasr AlFarabi. Ia juga ahli teori musik terbesar dalam Islam dan komponis beberapa irama musik, yang dapat didengarkan dalam dalam perbendaharaan lagu musik di India. al-Khawarizmi dengan teori aljabar, dan lainnya. Juga dalam bidang tasawuf tokoh yang akan selalu harus dalam sejarah seperti rabiah al-adawiyah dengan konsep mahabbah, alghazali dengan konsep wihdah as-syuhud, ibn 'Arabi dengan wihdah al-wujud, alBusthami dengan al-ittihad, al-Hallaj dengan al-hullul dan lainnya.

Akan tetapi seiring dengan berjalannya putaran sejarah dunia Islam terjadi kekakuan dan berhentinya perkembangan ilmu pengetahuan. Setidaknya kemacetan berawal dari hilangnya semangat kritis dalam menyikapi Pemikiran Islam. Umat Islam kehilangan inspirasi tentang pemikiran pendidikan. Islam kehilangan arah kiblat pendidikan dan terjadinya dikotomi ilmu pengetahuan. Teori-tori ilmu pengetahuan dianggap telah finish dan permasalahan yang ada sekarang penyelesaiannya hanya dapat dilakukan dengan merujuk kepada teori-teori ulama terdahulu diluar itu diangap menyalahi agama. Padahal keadaan jaman selalu berubah. Dunia muslim menganggap bahwa pintu ijtihad telah tertutup, hal ini mengakibatkan perkembangan ilmu pengetahuan Islam tidak mengalami perkembangan di zaman sekarang atau ke depan mengalami kejumudan dan tersisihkan oleh negara-negara barat.

Sikap seperti ini tentunya mengakibatkan ilmu bukan hanya berhenti mendadak akan tetapi membuat jurang pemisah dari kebenaran sejati. Sehingga kajian fikih terbelenggu dan fiqh oriented, pendekatan kalam menjadi minded, pendekatan sufistik menjadi tasauf oriented, dan seterusnya. Sebagai akibat lebih jauh mengarah pada terjadinya disintegrasi dalam tubuh umat Islam itu sendiri, karena masing-masing membawa isu mainstream atau standar hidup keislaman masing-masing (Muslih: 2005).

Keadaan ini didasarkan oleh persoalan epistemologi dalam khasanah pengetahuan Islam. Pesantren merupakan lembaga pendidikan yang inklusiv dan dinamis dalam menghadapi tantangan zaman. Pesantren secara umum harus senantiasa adaftif dalam menghadapi perubahan zaman dan bersikap inklusiv terhadap ilmu pengetahuan yang datang dari luar dirinya sehingga tidak akan lumpuh tertinggal dalam kemodernan.

Sebagaimana cita-cita KH. Ali Maksum Krapyak - Rois 'Am PBNU ke4 dan Pengasuh Pondok Pesantren AlMunawwir Krapyak Yogyakarta Pesantren meski ingin melahirkan duplikat Imam Hanafi, Imam Maliki, Imam Syafi'i, Imam Hambali, al-Ghazali, Nawawi, Suyuti, Asqalani, Miskawaih, Farabi, Kindi, Ibnu Sina, Ibnu Thufail, Jabir bin Hayyan, Khawarizmi, Battani, 
Ibnu Khaldun, Thantawi Jauhari, Ibnu Batutah, Muntanabbi, Ma'ari, Firdausi, Rumi, Abu Nawas, Abdul Qadir Jailani, Ibrahim Adam, Rabi'ah Adawiyah, Bistami, Junaidi Baghdadi, Syibli dan sebagainya (Badrun Alaina \& Humaidy Abdussami: 1995).

Setidaknya semangat epistemologi Popper, falsafikasi dapat dijadikan salah satu langkah untuk menyadarkan dan membangkitkan kembali gairah dan semangat ilmiah umat Islam. Islam niscaya inklusif terhadap pemikiran lain dan harus dengan percaya diri dengan menanggapi serangan paham lain. Keberanian untuk melahirkan hipotesa (konjektur) harus dibangkitkan. Serta kemauan untuk melahirkan kritik atau pembaruan dari teori-teori terdahulu yang tidak relevan dengan konteks kekinian juga harus dilakukan tanpa menghilangkan substansi dari nilai-nilai Islam. Didasari atau tidak, keenganan dan ketakutan untuk mengkritisi pandanganpandangan ulama terdahulu dengan dalih takut kualat atau bahkan pandangan tersebut tidak benar, menjadi penyebab enggannya generasi ilmu dalam umat untuk mengkaji ilmu-ilmu keagamaan. Bukan saja menjadikan kekakuan dalam memandang persoalan dunia dan kehidupannya akan tetap lebih buruk menjadi faktor utama digudangkannya warisan intelektual Islam. Pandangan konjektur dan falsifikasi Popper setidaknya mengusung konsep ijtihad yang hari ini telah tercabut dalam epistemologi Islam.

\section{PENUTUP}

Setelah penulis memaparkan pandangan falsifikasi Popper dalam makalah yang terbatas ini, kirannya dapat dipahami bahwa pengetahuan itu dapat dipeoleh melalui rasio atau akal dan pengalaman indra dengan jalan falsifikasi atau ilmu kritik. Dengan falsifikasi ilmu pengetahuan dapat berkembang dengan baik. Pengetahuan atau teori-teori yang ditemukan manusia bukanlah hasil final yang tidak bisa berubah. Pengetahuan bukan merupakan hal yang statis tetapi bisa mengalami perubahan dengan munculnya dinamika kehidupan. Bagi Popper, ilmu pengetahuan dikatakan berkembang jika terbukti atau ada kemungkinan salahnya (falsifiability), bisa disangkal (refutability) dan bisa diuji (testability).

Apabila teori dapat disalahkan melalui refutablity (disangkal) berarti teori tersebut harus digugurkan dan diganti dengan teori baru yang lebih tepat. Sebaliknya apabila suatu teori dapat bertahan melawan segala usaha penyangkalan, berarti teori tersebut semakin diperkokoh (corroboration). Dengan epistemologi Popper setidaknya bisa menggugah semangat kritis pemikiran pendidikan islam yang tidak relevan untuk zaman ini sehingga melahirkan teori-teori ilmiah baru yang dapat mengembangkan dunia pendidikan Islam dalam konteks kekinian guna membangun peradaban. Dalam semangat Falsifikasi Popper ini, kita tidak mesti harus membuang substansi dari ajaranajaran islam. Cara berpikir paradigmatik ini begitu penting sebagai dasar pijakan pengamatan dalam dunia pendidikan Pesantren. Suatu fenomena pendidikan berkemungkinan beda dalam hal pengkajian karena dilakukan oleh beberapa kelompok ahli dengan paradigma berbeda pula. Dengan itu kebenaran dalam ilmu pendidikan tidak dimonopoli oleh paradigma tertentu, tetapi merupakan kebenaran yang memuat banyak paradigma ilmu. 


\section{E. DAFTAR PUSTAKA}

Bertens, K, (1983). Filsafat Barat Kontemporer, Inggris Jerman, Jakarta: gramedia.

Muslih, Mohammad, (2004). Filsafat Ilmu: kajian atas asumsi dasar, paradigma dan kerangka teori ilmu pengetahuan, Yogyakarta: Belukar.

(2005). filsafat ilmu: kajian atas asumsi dasar, paradigma kerangka teori ilmu pengetahuan, cet. II. Yogyakarta: belukar.

Muntansyir, Rizal \& Misnal Munir, (2006). Filsafat Ilmu, Yogyakarta: Pustaka Pelajar.

sebagai Ilmu Kritis, Yogyakarta: Kanisus.

Nasr, Seyyed Hossein, (2009). Intelektual Islam, Yogyakarta: Pustaka Pelajar.

Popper, Karl R, (1992) conjectures and Refutations, London and New York: Routledge , (2000).

Realism And The Aim of Science, New York: Routledge. $\begin{array}{rrr}\text { Saut Pasaribu dan } & \text { Aji }\end{array}$ Sastrowardoyo, Logika Penemuan Ilmiah, Yogyakarta: Pustaka Pelajar.

Suseno, Franz Magnis, (2005). PijarPijar Filsafat, Yogyakarta: Kanisius. 